Астахова Елена Александровна, Ларионова Наталья Александровна, Панькова Людмила Николаевна, Чупрова Дина Борисовна

\title{
АНАЛИЗ СОВРЕМЕННОГО СОСТОЯНИЯ НАУЧНЫХ ИССЛЕДОВАНИЙ В СФЕРЕ КАДРОВОЙ БЕЗОПАСНОСТИ ${ }^{1}$
}

В статье представлен анализ современного состояния научных исследований понятия кадровой безопасности. Рассмотренные определения как российских, так и зарубежных авторов сгруппированы с точки зрения четырех подходов: как прочесс предупрежсдения отрицательных воздействий на безопасность; как элемент экономической безопасности; как состояние зациценности; как совокупность различных функций управления. Предложена авторская дефиниция рассматриваемой категории, выявлены факторы, сформулирована главная цель, задачи, определены угрозы и риски кадровой безопасности государства. Кроме этого, выделены уровни кадровой безопасности с точки зрения степени маситаба (территории), а также с точки зрения маситабности иелей, сроков их достижения и реализации.

Ключевые слова: кадровая безопасность, кадровая безопасность государства, факторы, иели, задачи, угрозы и риски кадровой безопасности.

Elena Astakhova, Natalia Larionova, Lyudmila Pankova, Dina Chuprova ANALYSIS OF THE CURRENT STATE OF SCIENTIFIC RESEARCH IN THE FIELD OF PERSONNEL SECURITY

The article presents an analysis of the current state of scientific research of the concept of personnel security. The definitions of both Russian and foreign authors are grouped in terms of four approaches: as a process of prevention of negative impacts on security; as an element of economic security; as a state of security; as a set of different management functions. The author's definition of the considered category is offered, factors are revealed, the main purpose, tasks are formulated, threats and risks of personnel security of the state are defined. In addition, the allocated levels of personnel security from the point of view of degree scale (area) and also from the point of view of the scale of the objectives, timelines and implementation.

Key words: personnel security, personnel security of the state, factors, goals, objectives, threats and risks of personnel security.

Bведение / Introduction. Современные процессы модернизации, происходящие в экономике как России, так и стран Евросоюза и направленные на поддержание стабильности и устойчивости социально-экономических и политических систем, обусловливают обеспечение национальной безопасности государства, важной составляющей которой выступает кадровая безопасность.

Многоаспектное понятие «кадровая безопасность» - достаточно новое, а потому направление обеспечения национальной безопасности является малоисследованным. В настоящее время наблюдается усиление взаимосвязи кадровой политики и политики укрепления национальной безопасности государства и их взаимозависимость.

Многофакторность феномена национальной безопасности предполагает выделение такой ее составляющей, как кадровая безопасность, или в общем смысле комплекс мер по предотвращению опасностей и рисков, связанных с персоналом, его трудовой деятельностью и использованием его интеллектуального потенциала.

\footnotetext{
Статья подготовлена в рамках гранта РФФИ № 18-010-00732 «Кадровая безопасность России в условиях геополитических изменений и поликультурной среды»
} 
Проблемам кадровой безопасности посвящены труды Д. Ю. Баглей, И. А. Борисова, М. А. Виноградовой, С. Б. Гиниевой, А. А. Гречишкиной, Л. Л. Калиниченко, А. Я. Кибанова, О. А. Кириченко, А. В. Козаченко, С. Н. Митякова, О. Ю. Литовченко, О. Ю. Лященко, Г. А. Назаровой, М. И. Петрова, В. П. Пономарева, Н. И. Реверчук, И. Г. Чумарина, И. П. Шульга, Л. А. Швайка и ряда других исследователей.

Кадровая безопасность на государственном уровне - сложное и неоднозначное понятие, недостаточно часто обсуждаемое в научной литературе, а в настоящее время требующее уточнения. Особенно мало исследований в сфере кадровой безопасности на уровне национальной экономической системы и экономических систем разного территориального уровня (федерального, регионального, местного).

Изменяющаяся геополитическая и макроэкономическая ситуация в России предопределяет необходимость изучения кадровой безопасности с точки зрения обеспечения национальной безопасности государства. Следует отметить, что Стратегия обеспечения национальной безопасности Российской Федерации расплывчато рассматривает вопросы обеспечения кадровой безопасности, что обусловливает необходимость конкретизации, легитимации и законодательного закрепления понятия «кадровая безопасность» как отдельной подсистемы национальной безопасности.

Maтериалы и методы / Materials and methods. В процессе исследования теоретических аспектов кадровой безопасности использовались методы теоретического и логического анализа, обобщения и сравнения.

Результаты и обсужсдение / Results and discussion. Понятие кадровой безопасности, как уже указывалось выше, относительно новое и рассматривается в основном в рамках менеджмента организации. Также следует отметить, что классического определения кадровой безопасности на сегодняшний день не существует, а поэтому трактуется авторами по-разному.

Некоторые авторы, такие как Х. Жидецькая, А. Кибанов, О. Кириченко, О. Литовченко, Л. Швайка, связывают понятие кадровой безопасности с процессом управленческого воздействия на формирование и регулирование человеческого капитала и считают, что безопасность - дело рук кадров. Другими словами, кадровая безопасность является одной из форм работы с персоналом - центральным звеном в ее формировании $[7,8,11,20]$.

Преимущественное большинство ученых, среди которых И. Бурда, С. Васильчак, Л. Калиниченко, Н. Махеда, Н. Маренич, М. Петров рассматривает кадровую безопасность как состояние защищенности от различных рисков и угроз $[3,4,6,12,16]$.

Существует также множество других подходов, применяющихся при трактовке сущности кадровой безопасности.

Анализируя все многообразие понятий, можно выделить четыре подхода к пониманию кадровой безопасности:

- $\quad$ как процесс предупреждения различных отрицательных воздействий на безопасность;

- $\quad$ как элемент экономической безопасности;

- как состояние защищенности;

- $\quad$ как совокупность различных функций управления, таких как планирование, организация, мотивация, контроль и координация.

Группировка понятий кадровой безопасности в соответствии с вышеназванными подходами представлена в таблице.

Таблица

Подходы к определению понятия «кадровая безопасность»

\begin{tabular}{|c|c|}
\hline Автор & Понятие \\
\hline \multicolumn{2}{|r|}{ Как элемент экономической безопасности } \\
\hline И. Бурда [3] & $\begin{array}{l}\text { Кадровая безопасность - это составляющая часть экономической безопасности пред- } \\
\text { приятия, приоритетными задачами которой является защита от угроз и рисков для соз- } \\
\text { дания условий наиболее эффективного управления персоналом как определяющего } \\
\text { ресурса для обеспечения высокого уровня конкурентоспособности предприятия }\end{array}$ \\
\hline
\end{tabular}




\begin{tabular}{|c|c|}
\hline Автор & Понятие \\
\hline С. Васильчак [4] & $\begin{array}{l}\text { Кадровая безопасность предприятия - это наиболее важная составляющая эконо-- } \\
\text { мической безопасности предприятия, целью которой является выявление, обезвре- } \\
\text { живание, предотвращение, отвод и предупреждение угроз, опасностей и рисков, } \\
\text { которые направлены на персонал и его интеллектуальный потенциал, и те, которые } \\
\text { идут непосредственно от него, что должно проявляться в системе управления тру- } \\
\text { довыми ресурсами и кадровой политике предприятия }\end{array}$ \\
\hline Л. Калиниченко [6] & $\begin{array}{l}\text { Кадровая безопасность - это такое состояние индивидуумов, коллектива предпри- } \\
\text { ятия, его человеческого потенциала и системы управления персона-лом, при ко- } \\
\text { тором обеспечивается эффективное использование экономического потенциала и } \\
\text { развитие предприятия }\end{array}$ \\
\hline $\begin{array}{l}\text { Н. Махеда, } \\
\text { Н. Маренич [12] }\end{array}$ & $\begin{array}{l}\text { Кадровая безопасность - это комбинация таких составляющих частей, как безопас- } \\
\text { ность жизнедеятельности, социально-мотивационная, профессиональ-ная и анти- } \\
\text { конфликтная безопасность рисков компании, связанных с ее составляющей }\end{array}$ \\
\hline М. Петров [16] & $\begin{array}{l}\text { Кадровая безопасность - это такое положение организации как социальной общ- } \\
\text { ности и индивида в ней, при котором воздействие на них со стороны природной, } \\
\text { экономической и социальной сред, а также внутренней среды самого человека не } \\
\text { способны причинить вред }\end{array}$ \\
\hline \multicolumn{2}{|c|}{ Как процесс предупреждения отрицательных воздействий на безопасность } \\
\hline А. Гречишкина [5] & $\begin{array}{l}\text { Кадровая безопасность - это процесс предупреждения, предотвращения и устра- } \\
\text { нения рисков и угроз, которые возникают со стороны персонала, с целью создания } \\
\text { условий для стабильного функцонирования и развития предприятия }\end{array}$ \\
\hline $\begin{array}{l}\text { В. Козаченко, } \\
\text { В. Пономарев, } \\
\text { О. Ляшенко [9] }\end{array}$ & $\begin{array}{l}\text { Кадровая безопасность - это процесс предотвращения отрицательных влияний на } \\
\text { экономическую безопасность предприятия за счет рисков и угроз, связанньх с пер- } \\
\text { соналом, его интеллектуальньм персоналом и трудовыми отношениями в целом }\end{array}$ \\
\hline Н. Реверчук [17] & $\begin{array}{l}\text { Кадровая безопасность предприятия состоит в предупреждении и уменьшении опас- } \\
\text { ности отрицательного влияния на экономическую безопасность недостаточно ква- } \\
\text { лифицированных работников предприятия, неэффективного управления персоналом } \\
\text { касательно сохранения и развития интеллектуального потенциала предприятия }\end{array}$ \\
\hline Г. Чумарин [18] & $\begin{array}{l}\text { Кадровая безопасность - это процесс предупреждения отрицательных влияний на } \\
\text { экономическую безопасность предприятия за счет рисков и угроз, связанных с пер- } \\
\text { соналом, его интеллектуальным потенциалом и трудовыми отношениями }\end{array}$ \\
\hline \multicolumn{2}{|r|}{ Как состояние защиценности } \\
\hline Д. Баглей [1] & $\begin{array}{l}\text { Кадровая безопасность - это состояние защищенности хозяйствующего субъекта от } \\
\text { кадровых опасностей и угроз посредством эффективного управления персоналом }\end{array}$ \\
\hline $\begin{array}{l}\text { И. Борисов, } \\
\text { С. Гиниева [2] }\end{array}$ & $\begin{array}{l}\text { Кадровая безопасность - это состояние общества, которое достигается за счет де- } \\
\text { ятельности, направленной на формирование качественных и количественных ха- } \\
\text { рактеристик профессионального потенциала трудоспособных граждан, обеспечи- } \\
\text { вающих сохранение целостности и развития общества, суверенитет государства, } \\
\text { отсутствие рисков потери конкурентоспособности в различных секторах эконом- } \\
\text { ки. Это защита общества от угроз и рисков непрофессионализма, деструктивного } \\
\text { профессионализма, сохранение и развитие профессионального потенциала через } \\
\text { эффективное функцонирование различньх уровней кадровой политики - госу- } \\
\text { дарственной, региональной, муниципальной и кадровой политики организации }\end{array}$ \\
\hline О. Лащенко [14] & $\begin{array}{l}\text { Кадровая безопасность - это состояние экономической системы, при котором про- } \\
\text { исходит эффективное взаимодействие всех ее функщиональных составляющих }\end{array}$ \\
\hline $\begin{array}{l}\text { С. Митяков, } \\
\text { М. Ширяев, } \\
\text { Н. Яковлева, } \\
\text { Чжао Цонли [13] }\end{array}$ & $\begin{array}{l}\text { Кадровая безопасность региона - элемент экономической безопасности, процесс } \\
\text { предотвращения негативных воздействий на экономическую безопасность за счет } \\
\text { рисков и угроз, связанных с человеческими ресурсами региона, интеллектуальным } \\
\text { потенциалом и трудовыми отношениями }\end{array}$ \\
\hline А. Шаваев [19] & $\begin{array}{l}\text { Кадровая безопасность - состояние защищенности общественно-прогрессивных } \\
\text { интересов организации по развитию и усовершенствованию ее человеческого ка- } \\
\text { питала, поддержке эффективной системы управления человеческими ресурсами и } \\
\text { минимизации рисков компании, связанных с ее кадровой составляющей }\end{array}$ \\
\hline
\end{tabular}




\begin{tabular}{|c|c|}
\hline Автор & Понятие \\
\hline И. Шульга [21] & $\begin{array}{l}\text { Кадровая безопасность - это обеспеченность предприятия кадровыми ресурсами, } \\
\text { формирование эффективной системы управления персоналом и коммуникацион- } \\
\text { ной политики }\end{array}$ \\
\hline \multicolumn{2}{|r|}{ Как совокупность функций } \\
\hline А. Кибанов [7] & $\begin{array}{l}\text { Кадровая безопасность - это генеральное направление кадровой работы, сово- } \\
\text { купность принципов, методов, форм организационного механизма по разработке } \\
\text { целей, задач, направленных на сохранение, укрепление и развитие кадрового по- } \\
\text { тенциала, на создание ответственного и высокопроизводи-тельного сплоченного } \\
\text { коллектива, способного своевременно реагировать на постоянно меняющиеся тре- } \\
\text { бования рынка с учетом стратегии развития организации }\end{array}$ \\
\hline О. Кириченко[8] & $\begin{array}{l}\text { Кадровая безопасность - правовое и информационное обеспечение процесса } \\
\text { управления персоналом: решение правовых вопросов трудовых отношений, под- } \\
\text { готовка нормативных документов, обеспечение необходимой информацией всех } \\
\text { подразделений управления персоналом. }\end{array}$ \\
\hline $\begin{array}{l}\text { Г. Крохичева, } \\
\text { Э. Архипов, } \\
\text { М. Виноградова, } \\
\text { Д. Деточка [10] }\end{array}$ & $\begin{array}{l}\text { Кадровая безопасность - некое состояние человеческого капитала, оптимально } \\
\text { взаимодействующее друг с другом, направленное на формирование качест-венных } \\
\text { и количественных профессиональных характеристик с особым акцентом на потен- } \\
\text { циал, обеспечение сохранности целостности и стабильного развития общества в } \\
\text { целом и индивида в частности при условии нивелирования угроз потери самодо- } \\
\text { статочности в различных отраслях науки, техники, образования и иных сферах де- } \\
\text { ятельности, а также оптимизации кадровой политики организации и государства }\end{array}$ \\
\hline О. Литовченко [11] & $\begin{array}{l}\text { Кадровая безопасность - это совокупность управленческих мероприятий, свя- } \\
\text { занных с эффективным формированием и использованием кадрового потенциала } \\
\text { предприятия с целью обеспечения и поддержки экономической устойчивости и ре- } \\
\text { зультативности хозяйственной деятельности предприятия }\end{array}$ \\
\hline Г. Назарова [15] & $\begin{array}{l}\text { Кадровая безопасность - это деятельность по созданию условий для стабильного } \\
\text { функционирования и развития компании, при которых обеспечивается гарантиро- } \\
\text { ванная законодательством защищенность интересов компании и собственников от } \\
\text { рисков и угроз, связанных с персоналом }\end{array}$ \\
\hline $\begin{array}{l}\text { Л. Швайка, } \\
\text { Х. Жидецькая [20] }\end{array}$ & $\begin{array}{l}\text { Кадровая безопасность - это совокупность средств (инструментария), с помощью } \\
\text { которых администрация предприятия способствует сохранению, укреплению и } \\
\text { развитию персонала для обеспечения эффективного функцинирования организа- } \\
\text { ции и защиты от рисков, связанных с работниками }\end{array}$ \\
\hline
\end{tabular}

Под кадровой безопасностью государства авторами понимается состояние человеческого капитала государства, направленное на формирование и развитие качественных и количественных профессиональных характеристик, выявление потенциала общества в целом и индивида в частности, это защищенность государства от кадровых угроз и опасностей посредством функционирования эффективного механизма управления человеческими ресурсами.

В подходах к кадровой безопасности с точки зрения масштаба (территории), на наш взгляд, можно выделить следующие уровни:

- персональный;

- профессиональный (профессиональных сообществ);

- общекорпоративный (организационный);

- отраслевой;

- территориальный (муниципалитет, регион, страна в целом).

С точки зрения масштабности целей, сроков их достижения и реализации можно выделить уровни:

- стратегический;

- тактический;

- оперативный.

Условия обеспечения кадровой безопасности государства представлены на рисунке. 


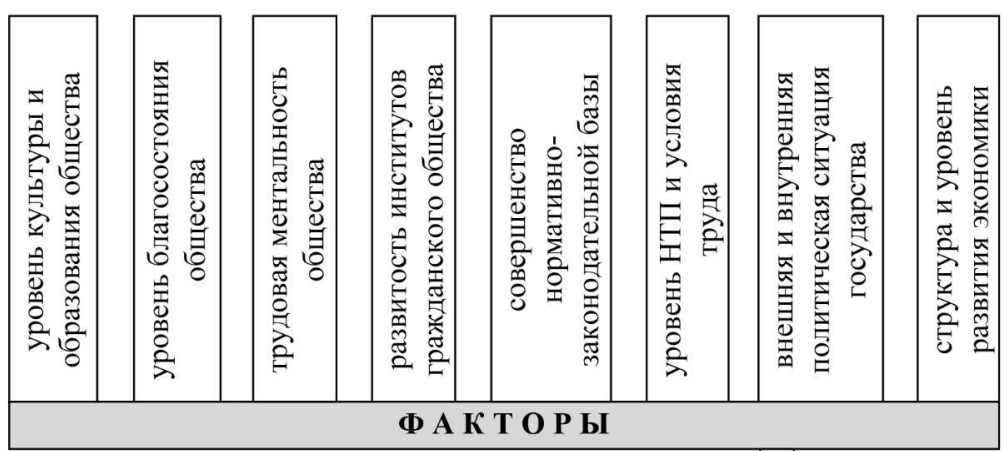

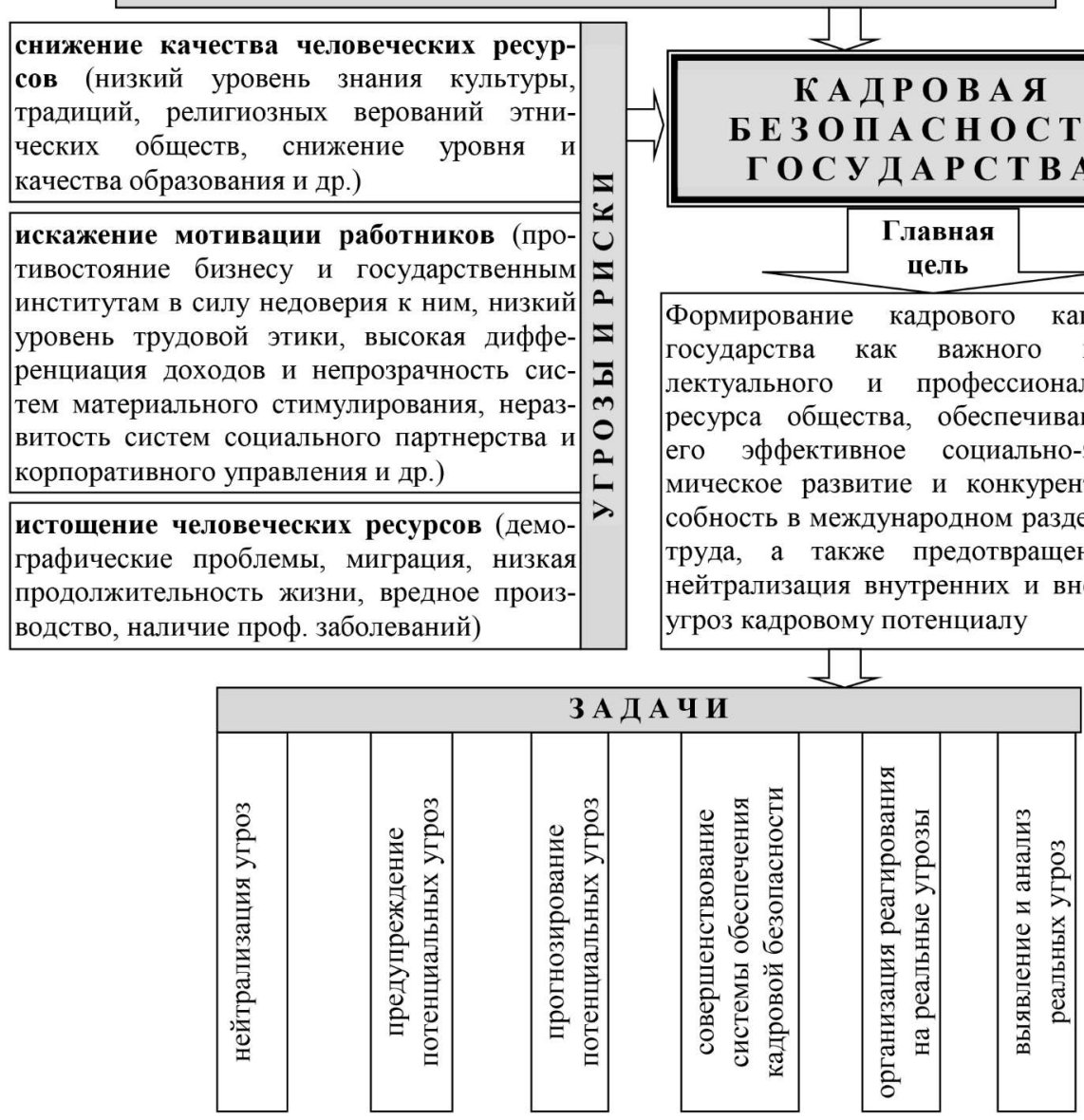

Рис. Условия обеспечения кадровой безопасности государства

В стратегической перспективе целью кадровой безопасности общества выступает формирование кадрового капитала страны как важного интеллектуального и профессионального ресурса общества, обеспечивающего его эффективное социально-экономическое развитие и конкурентоспособность в международной системе разделения труда. Тактический и оперативный уровни кадровой безопасности реализуются в различных программах и методиках.

Уровень национальной кадровой безопасности во многом обеспечивается развитым политическим институтом государственной гражданской службы с точки зрения уровня профессионального развития, квалификации, персональной зрелости государственных служащих, а также мировоззренческих ценностей, первоочередностью государственных и общественных интересов 
России и приоритетных мотивов служения ей. Развитость политического института государственной гражданской службы обусловливает эффективность реализации государственной, региональной, муниципальной кадровой политики, направленной на снижение рисков и угроз, связанных с кадровыми ресурсами.

Все структурные компоненты кадровой безопасности зависят как от количественных, так и от качественных характеристик профессионального потенциала, таких как:

- уровень образования, культуры и благосостояния;

- количественные и качественные характеристики трудового потенциала, его общая и профессиональная трудоспособность;

- качество и количество занятого населения, непосредственно производящего структурные компоненты безопасности;

- наличие механизмов «карьерных лифтов»;

- уровень кадровой культуры руководителей;

- уровень развития институтов гражданского общества, предотвращающих продвижение к власти безнравственных и «бесталанных» граждан, противостоящих протекционизму, волюнтаризму и преобладанию в кадровой политике (в том числе в системе государственного и муниципального управления) принципов личной преданности, родственных связей, землячества, и др.

Учитывая, что кадровая безопасность - это составляющая экономической безопасности, можно сказать, что она нацелена на предотвращение экономических рисков и обеспечение экономической стабильности общества посредством формирования трудовых ресурсов, обладающих соответствующим интеллектуальным потенциалом, и социально-трудовых отношений, поддерживающих данный процесс (встречается название «кадровая и интеллектуальная составляющие»).

Незавершенность процессов институционализации государственной кадровой политики современной России создает множество угроз кадровой безопасности.

Можно выделить виды угроз кадровой безопасности и сформулировать способы их предотвращения, сглаживания. В научной литературе чаще всего применяется следующая классификация угроз кадровой безопасности [10]:

- угроза истощения человеческих ресурсов;

- угроза искажений мотивации наемных работников;

- угроза снижения качества человеческих ресурсов.

Первый вид угроз (истощения человеческих ресурсов) проявляется в России в виде различного рода демографических проблем, невысокой продолжительности жизни и трудовой деятельности граждан, наличия вредных производств и роста числа профессиональных заболеваний.

Исходя из характера и основных факторов такого вида угрозы кадровой безопасности для ее нивелирования следует осушествлять действия, направленные на увеличение числа трудоспособных граждан в стране: решение демографических проблем, повышение безопасности труда и совершенствование его охраны, развитие системы здравоохранения и социальной защиты, изменение пенсионного законодательства и др.

Угроза искажений мотивации работников наиболее ярко проявляется в России в противостоянии бизнесу и государственным институтам в силу недоверия к ним граждан, низкая приверженность организации и недостаточно высокий уровень трудовой этики, высокая дифференциация доходов и непрозрачность систем материального стимулирования, неразвитость систем социального партнерства и корпоративного управления и др.

Система мер, направленных на снижение данного вида угрозы, должна быть направлена на повышение роли наемного работника в управлении, рост его заинтересованности в развитии организации, обеспечение максимальной открытости и прозрачности руководящих действий на всех уровнях управления, рост доходов работников и др. 
Угроза снижения качества человеческих ресурсов в России проявляется в постепенном снижении всех уровней образования, повышении доступности получения высшего образования, и, как следствие, в потере качества, отрыве процесса образования от практики, чрезмерной коммерциализации образования и др.

Для решения проблем и нейтрализации данной угрозы, необходимо возрождение отечественных традиций школьного образования, сокращение количества вузов, повышение практической направленности образования, привлечение потенциальных работодателей к процессу подготовки специалистов и др.

Развитие науки и общества, а также практика современного государственного управления предопределяет необходимость использования инновационных технологий, внедрение которых невозможно без изменения системы ценностей, образа мышления, без развития человеческого потенциала. Необходимыми факторами снижения кадровых угроз национальной безопасности являются: профессионализм, надежность, стабильность и оперативность функционирования государственного аппарата. Причем важнейшая роль заключается в формировании качественного состава управленческих кадров на основе инновационного подхода к реализации современной государственной кадровой политики и обеспечению кадровой безопасности.

Важное значение в укреплении кадровой безопасности страны, наряду с органами управления и кадрами государственной службы, имеют общественные движения и организации, политические партии, экономические институты и средства массовой информации.

Заключение / Conclusion. В условиях нестабильного экономического и политического положения нашего государства на мировой арене проблема безопасности становится очень актуальной. В соответствии с процессами глобализации, с одной стороны, происходит обострение проблем в вопросах кадровой безопасности, с другой стороны, возрастает возможность привлечения уникальных кадров в определенных направлениях или сферах деятельности независимо от страновой принадлежности. В этих условиях необходимо изменить отношение к человеку-профессионалу для получения преимуществ в формировании кадрового потенциала государства.

\section{ЛИТЕРАТУРА И ИНТЕРНЕТ-РЕСУРСЫ}

1. Баглей Д. Ю. Технологии кадрового менеджмента в системе экономической безопасности предпринимательства: автореф. дис. ... канд. экон. наук. Ростов-н/Д., 2007. 35 с.

2. Борисов И. А., Гиниева С. Б. Кадровая безопасность России: ключевые проблемы и пути решения // Достойный труд - основа стабильного общества: мат-лы VI Междунар. науч.-практ. конф.: в 2 т. Т. 1. Екатеринбург: Изд-во Урал. гос. экон. ун-та, 2014. 290 с.

3. Бурда И. Я. Экономическая безопасность предприятия и место в ней кадровой безопасности [Электронный ресурc]. URL: http: // economy.nauka.com.ua/index.php.

4. Васильчак С. В. Кадровая безопасность предпринимательства - основа экономического развития // Научный вестник НЛТУ Украины. 2009. Вып. 19.12. С. 122-128.

5. Гречишкина А. А. Сущность понятия «кадровая безопасность» предприятий железнодорожного транспорта // Научный вестник Херсонского государственного университета. Серия «Экономические науки». 2014. Вып. 6. Ч. 2. С. 144-146.

6. Калиниченко Л. Л. Методологический подход к управлению персоналом предприятий железнодорожного транспорта в условиях реформирования отрасли: монография. Харьков: УкрДазт, 2012. 382 с.

7. Кибанов А. Я. Управление персоналом организации: учебник. М.: ИНФРА-М, 2002. 638 с.

8. Кириченко О. А. Менеджмент внешнеэкономической деятельности: учеб. пособие. 3-е изд., перераб. и доп. Киев: Знание-Пресс, 2002. 384 с.

9. Козаченко А. В., Пономарев В. П., Ляшенко О. М. Экономическая безопасность предприятия: сущность и механизмы обеспечения: монография. Киев: Либра, 2003. 280 с.

10. Крохичева Г. Е. Кадровая безопасность в системе экономической безопасности / Г. Е. Крохичева, Э. Л. Архипов, М. А. Виноградова, Д. Е. Деточка // Интернет-журнал «НАУКОВЕДЕНИЕ». Т. 8. № 3 (2016). URL: http://naukovedenie.ru/PDF/94EVN316.pdf 
11. Литовченко О. Ю. Формирование кадровой безопасности предприятий АПК: автореф дис. ... канд. экон. наук. Киев, 2010. 26 с.

12. Махеда Н. Г., Маренич А. И. Социально-мотивационные составляющие кадровой безопасности // Финансовый журнал: международный научно-практический журнал / Черкасский институт банковского дела НБУ (г. Киев). 2012. № 2(6). С. 38-45.

13. Митяков С. Н. Кадровая безопасность как один из ключевых факторов экономической безопасности региона / С. Н. Митяков, М. В. Ширяев, Н. Н. Яковлева, Ц. Чжао // Экономическая безопасность России: проблемы и перспективы: мат-лы II Международной научно-практической конференции. Нижний Новгород: Нижегородский государственный технический университет имени Р. Е. Алексеева, 2014. С. 216-221.

14. Лященко О. Ю. Кадровая безопасность как подсистема в системе экономической безопасности предприятия [Электронный ресурс] / O. Ю. Лященко. URL: http: // www. nbuv.gov.ua /e-journals/ pspe2007-3/laschenko_307.htm.

15. Назарова Г. Предпосылки создания системы кадровой безопасности предприятия // Региональные аспекты развития производительных сил Украины: науч. журн. / Терноп. нац. экон. ун-т. 2010. Вып. 15. C. 34-37.

16. Петров М. И. Экономическая безопасность предприятия: сущность, трактовки, точки зрения // Менеджер. 2002. № 1(17). С. 67-71.

17. Реверчук Н. И. Управление экономической безопасностью предпринимательских структур. Львов: ЛБИ НБУ, 2004. 195 с.

18. Чумарин И. Г. Функции и задачи службы персонала в области обеспечения экономической безопасности // Кадры предприятия. 2003. № 3(03). С. 31.

19. Шаваев А. Г. Безопасность корпораций. Криминологические, уголовно-правовые и организационные проблемы. М.: Банковский Деловой Центр, 2007. 239 с.

20. Швайка Л. А., Жидецькая Х. В. Некоторые вопросы сущности кадровой безопасности предприятия // Полиграфия и издательское дело. 2012. № 4 (56). С. 158-163.

21. Шульга И. П. Экономическая безопасность эмиссионной деятельности акционерных обществ: монография. Черкассы: Маклаут, 2010. 425 с.

\section{REFERENCES AND INTERNET RESOURCES}

1. Baglej D. Ju. Tehnologii kadrovogo menedzhmenta $\mathrm{v}$ sisteme jekonomicheskoj bezopasnosti predprinimatel'stva (Technologies of personnel management in the system of economic security of entrepreneurship): avtoref. dis. ... kand. jekon. Nauk. Rostov-n/D., 2007. 35 s.

2. Borisov I. A., Ginieva S. B. Kadrovaja bezopasnost' Rossii: kljuchevye problemy i puti reshenija (Personnel security in Russia: key problems and solutions) // Dostojnyj trud - osnova stabil'nogo obshhestva: materialy VI Mezhdunar. nauch.-prakt. konf.: v 2 t. T. 1. Ekaterinburg: Izd-vo Ural. gos. jekon. un-ta, 2014. 290 s.

3. Burda I. Ja. Jekonomicheskaja bezopasnost' predprijatija i mesto v nej kadrovoj bezopasnosti (Economic security of the enterprise and the place of personnel security in it) [Elektronnyj resurs]. URL: http: // economy.nauka.com.ua/index.php.

4. Vasil'chak S. V. Kadrovaja bezopasnost' predprinimatel'stva - osnova jekonomicheskogo razvitija (Personnel security entrepreneurship - based economic development) // Nauchnyj vestnik NLTU Ukrainy. 2009. Vyp. 19.12. S. 122-128.

5. Grechishkina A. A. Sushhnost' ponjatija «kadrovaja bezopasnost'» predprijatij zheleznodorozhnogo transporta (The essence of the concept «human security» enterprises of a railway transport) // Nauchnyj vestnik Hersonskogo gosudarstvennogo universiteta. Serija «Jekonomicheskie nauki». 2014. Vyp. 6. Ch. 2. S. $144-146$.

6. Kalinichenko L. L. Metodologicheskij podhod k upravleniju personalom predprijatij zheleznodorozhnogo transporta v uslovijah reformirovanija otrasli: monografija (Methodological approach to personnel management of railway transport enterprises in the context of industry reform). Har'kov: UkrDazt, 2012. $382 \mathrm{~s}$.

7. Kibanov A. Ja. Upravlenie personalom organizacii (The management staff of the organization): uchebnik. M.: INFRA-M, 2002, 638 p. 
8. Kirichenko O. A. Menedzhment vneshnejekonomicheskoj dejatel'nosti (Management of foreign economic activity): ucheb. posobie. 3-e izd., pererab. i dop. Kiev: Znanie-Press, 2002. 384 s.

9. Kozachenko A. V., Ponomarev V. P., Ljashenko O. M. Jekonomicheskaja bezopasnost' predprijatija: sushhnost' i mehanizmy obespechenija (Economic security of the enterprise: the essence and mechanisms of ensuring): Monografija, Kiev: Libra, 2003. $280 \mathrm{~s}$.

10. Krohicheva G. E. Kadrovaja bezopasnost' v sisteme jekonomicheskoj bezopasnosti (Personnel security in the system of economic security) / G. E. Krohicheva, Je. L. Arhipov, M. A. Vinogradova, D. E. Detochka // Internet-zhurnal «NAUKOVEDENIE». Tom 8. No. 3 (2016). URL: http://naukovedenie.ru/ PDF/94EVN316.pdf

11. Litovchenko O. Ju. Formirovanie kadrovoj bezopasnosti predprijatij APK (Formation of personnel security of agricultural enterprises): avtoreferat dis. ... kand. jekon. nauk. Kiev, 2010. $26 \mathrm{~s}$.

12. Maheda N. G., Marenich A. I. Social'no-motivacionnye sostavljajushhie kadrovoj bezopasnosti (Sociomotivational components of human security) // Finansovyj zhurnal: mezhdunarodnyj nauchno-prakticheskij zhurnal / Cherkasskij institut bankovskogo dela NBU. 2012. No. 2 (6). S. 38-45.

13. Mitjakov S. N. Kadrovaja bezopasnost' kak odin iz kljuchevyh faktorov jekonomicheskoj bezopasnosti regiona (Personnel security as one of the key factors of economic security of the region) / S. N. Mitjakov, M. V. Shirjaev, N. N. Jakovleva, C. Chzhao // Jekonomicheskaja bezopasnost' Rossii: problemy i perspektivy: materialy II Mezhdunarodnoj nauchno-prakticheskoj konferencii. Nizhnij Novgorod: Nizhegorodskij gosudarstvennyj tehnicheskij universitet imeni R. E. Alekseeva, 2014. S. 216-221.

14. Ljashhenko O. Ju. Kadrovaja bezopasnost' kak podsistema v sisteme jekonomicheskoj bezopasnosti predprijatija (Personnel security as a subsystem in the system of economic security of the enterprise) [Elektronnyj resurs]. URL: http://www.nbuv.gov.ua/e-journals/pspe2007-3/laschenko_307.htm.

15. Nazarova G. O. Predposylki sozdanija sistemy kadrovoj bezopasnosti predprijatija (Prerequisites for creating a system of personnel security of the enterprise) // Regional'nye aspekty razvitija proizvoditel'nyh sil Ukrainy: nauch. zhurn. / Ternop. nac. jekon. un-t. 2010. Vyp. 15. S. 34-37.

16. Petrov M. I. Jekonomicheskaja bezopasnost' predprijatija: sushhnost', traktovki, tochki zrenija (Economic security of the enterprise: essence, interpretations, points of view) // Menedzher. 2002. № 1(17). S. 67-71.

17. Reverchuk N. I. Upravlenie jekonomicheskoj bezopasnost'ju predprinimatel'skih struktur (Management of economic security of business structures). L'vov: LBI NBU, 2004. $195 \mathrm{~s}$.

18. Chumarin I. G. Funkcii i zadachi sluzhby personala v oblasti obespechenija jekonomicheskoj bezopasnosti (Functions and tasks of the personnel service in the field of economic security) // Kadry predprijatija. 2003. No 3(03). S. 31.

19. Shavaev A. G. Bezopasnost' korporacij. Kriminologicheskie, ugolovno-pravovye i organizacionnye problem (Corporate security. Criminological, criminal law and organizational problems). M.: Bankovskij Delovoj Centr, 2007. $239 \mathrm{~s}$.

20. Shvajka L. A. Nekotorye voprosy sushhnosti kadrovoj bezopasnosti predprijatija (Some issues of entity personnel safety enterprises) // Poligrafija i izdatel'skoe delo. 2012, No 4 (56). S. 158-163.

21. Shul'ga I. P. Jekonomicheskaja bezopasnost' jemissionnoj dejatel'nosti akcionernyh obshhestv (Economic security of issue activity of joint-stock companies): monografija. Cherkassy: Maklaut, 2010. $425 \mathrm{~s}$.

\section{СВЕДЕНИЯ ОБ АВТОРАХ}

Aстахова Елена Александровна, кандидат экономических наук, доцент, доцент кафедры государственного и муниципального управления Института экономики и управления Северо-Кавказского федерального университета, г. Ставрополь, Россия. E-mail: astachova123@yandex.ru

Ларионова Наталья Александровна, кандидат экономических наук, доцент, доцент кафедры государственного и муниципального управления Института экономики и управления Северо-Кавказского федерального университета, г. Ставрополь, Россия. E-mail: LN@vip-line.ru

Панькова Людмила Николаевна, кандидат экономических наук, доцент, доцент кафедры государственного и муниципального управления Института экономики и управления Северо-Кавказского федерального университета, г. Ставрополь, Россия. E-mail: ludmilaganshina@rambler.ru

Чупрова Дина Борисовна, кандидат экономических наук, доцент, доцент кафедры государственного и муниципального управления Института экономики и управления Северо-Кавказского федерального университета, г. Ставрополь, Россия. E-mail: dina.chyprova@mail.ru 


\section{INFORMATION ABOUT AUTHORS}

Astakhova Elena, Candidate of Economic Sciences, associate Professor, of chair of state and municipal management, Institute of Economics and management, North Caucasus Federal University. E-mail: astachova123@ yandex.ru

Larionova Natalia, Candidate of Economic Sciences, associate Professor, of chair of state and municipal management, Institute of Economics and management North Caucasus Federal University. E-mail: LN@ vip-line.ru

Pankova Lyudmila, Candidate of Economic Sciences, associate Professor, of chair of state and municipal management, Institute of Economics and management, North Caucasus Federal University. E-mail: ludmilaganshina@rambler.ru

Chuprova Dina, Candidate of Economic Sciences, associate Professor, of chair of state and municipal management, Institute of Economics and management, North Caucasus Federal University. E-mail: dina.chyprova@mail.ru

Боровикова Наталья Владимировна, Тер-Григорьянц Анна Александровна

\section{ПРОБЛЕМЫ И ПЕРСПЕКТИВЫ РЕАЛИЗАЦИИ ПОЛИТИКИ ИМПОРТОЗАМЕЩЕНИЯ В ПРОМЫШЛЕННОСТИ СЕВЕРО-КАВКАЗСКОГО ФЕДЕРАЛЬНОГО ОКРУГА}

На основе изучения эволючии научной мысли в области размещения промылиленности в пространстве доказана необходимость реализации экономической политики импортозамещения в отдельных территориальных образованиях. Ндентификация проблем разработки и реализации политики импортозамещения на Северном Кавказе позволила сфориулировать основныле направления обеспечения в долгосрочной перспективе эффективности промышленной политики в регионах Северо-Кавказского федерального округа с учетом обиемировых трендов и современных достижений науки и техники.

Ключевые слова: промыиленность, политика, импортозалещение, регион, индикаторы, точки промылиленного роста, стратегическая значимость, Северо-Кавказский федеральный округ.

\section{Natalia Borovikova, Anna Ter-Grigoryants \\ PROBLEMS AND PROSPECTS OF IMPLEMENTATION OF THE POLICY OF IMPORT SUBSTITUTION IN INDUSTRY OF THE NORTH CAUCASIAN FEDERAL DISTRICT}

On the basis of the study of the evolution of scientific thought in the field of industry placement in space, the necessity of implementation of the economic policy of import substitution in certain territorial entities is proved. Identification of problems of development and implementation of import substitution policy in the North Caucasus allowed to formulate the main directions of ensuring the long-term effectiveness of industrial policy in the regions of the North Caucasus Federal district, taking into account global trends and modern achievements of science and technology.

Key words: industry, politics, import substitution, region, indicators, points of industrial growth, strategic importance, North Caucasus Federal district.

Bведение / Introduction. В условиях усиливающейся глобализации в системе национальной безопасности любой страны мира особая роль отводится экономической безопасности. Каждое государство, каждый регион характеризуются своими особыми географическими характеристиками, что ставит их в неравное положение по отношению друг к другу. Территориальное 